\title{
Evaluasi Pengelolaan Lansekap Monumen Puputan Klungkung sebagai Tapak Bersejarah
}

\author{
NI MADE CLASSIA SUKENDAR, A.A. GEDE SUGIANTHARA*, \\ NI WAYAN FEBRIANA UTAMI \\ Program Studi Arsitektur Pertamanan, Fakultas Pertanian, Universitas Udayana \\ JI. PB. Sudirman, Denpasar 80232 Bali \\ *E-mail: sugianthara@unud.ac.id
}

\section{ABSTRACT \\ An Evaluation of Landscape Management of Puputan Klungkung Monument As a Historic Site}

The landscape of Puputan Klungkung Monument is a historical site which doesn't have optimal managemet therefore it is necessary an evaluation on landscape management of the site. The purpose of this research was to discover the pertinent concept of landscape management in Puputan Klungkung Monument applied by the Department of Cultural and Tourism of Klungkung District as well as to provide recommendations in order to improve the site. The research method used were field survey with observation, interviews, questionnaires and literature study technic. Results showed that the solution consist of the main and supporting recommendations. The main recommendations was spatial management for Puputan Klungkung Monument such as recommendation on space, circulation and vegetation. In addition, the supporting solutions was biophysical (facilities and maintenance improvement), cultural and social (effectiveness and service improvement, preparing tour packages), policy (to establish a specialized management agency, to compose Standard Operating Procedure of Puputan Klungkung Monument), and also economic (to use electronic card for entrance ticket). It can be concluded that the management implementation of monument was achieved as much as $80 \%$ based on Tupoksi. Hence, it was important to establish a specialized management agency to compose SOP of Puputan Klungkung Monument.

Keywords: historical site, landscape evaluation, landscape management, Puputan Klungkung monument

\section{Pendahuluan}

Monumen Puputan Klungkung penting diketahui masyarakat, karena didirikan untuk mengenang perjuangan rakyat Kerajaan Klungkung melawan kolonialisme Belanda, juga difungsikan sebagai objek wisata. Tapak ini dikatakan sebagai tapak bersejarah karena memiliki catatan penting akan peristiwa perang Puputan Klungkung. Penelitian dilakukan di Klungkung dikarenakan Klungkung memiliki sebuah monumen yang merupakan tapak berlangsungnya perang terakhir era kerajaan di Bali yaitu 28 April 1908. Monumen Puputan Klungkung diresmikan tanggal 28 April 1992 dan direncanakan oleh Ida Ayu Armely. Konsep desain monumen mengacu pada tanggal kejadian Perang Puputan 
Klungkung dan bentuk dari monumen yaitu lingga dan yoni. Coretan dibagian dinding dan pintu monumen, anjing dapat masuk ke dalam monumen, tiang gazebo rusak dimakan rayap, rumput mati serta kurangnya pemangkasan pada tanaman mengesankan bagian dalam dan luar monumen pun kurang mendapatkan perawatan serta penjagaan.

Dinas Pariwisata Daerah Provinsi Bali (2016), jumlah kunjungan wisatawan tahun 2014 ke objek wisata Kertha Gosa mencapai 13,95\%, Goa Lawah 17,95\%, Kawasan Nusa Penida 67,20\% dan Levi Rafting 0,9\%. Kunjungan wisatawan tahun 2015 ke objek wisata Kertha Gosa 11,7\%, Goa Lawah 15,50\%, Kawasan Nusa Penida 71,20\% dan Levi Rafting $1,60 \%$. Data menunjukkan wisatawan yang berkunjung ke Kertha Gosa dan Goa Lawah mengalami penurunan, sedangkan wisatawan yang berkunjung ke Kawasan Nusa Penida dan Levi Rafting mengalami kenaikan. Kunjungan wisatawan ke Monumen Puputan Klungkung tidak ada data. Berdasarkan kondisi lansekap monumen dan kunjungan wisatawan monumen, lansekap Monumen Puputan Klungkung kurang mendapatkan pengelolaan yang optimal, sehingga evaluasi pengelolaan lansekap perlu dilakukan. Acuan yang digunakan untuk mengevaluasi yaitu dengan aspek-aspek pengelolaan yang terdiri dari biofisik, sosial budaya, kebijakan, ekonomi.

Rumusan masalah yang diangkat adalah bagaimana konsep pengelolaan lansekap monumen yang diterapkan oleh Dinas Kebudayaan dan Pariwisata (DISBUDPAR) Kabupaten Klungkung serta apa saja solusi untuk meningkatkan pengelolaan lansekap monumen. Tujuan penelitian ini adalah mengetahui dan memahami konsep pengelolaan lansekap monumen yang diterapkan oleh DISBUDPAR Kabupaten Klungkung, serta membuat rekomendasi berupa solusi yang dapat digunakan untuk meningkatkan pengelolaan lansekap monumen. Manfaat yang didapatkan dari penelitian ini adalah menambah pengetahuan mengenai konsep pengelolaan lansekap Monumen Puputan Klungkung, sebagai referensi untuk penelitian sejenis selanjutnya, serta dapat memberi sumbangan berupa masukan kepada pihak DISBUDPAR Kabupaten Klungkung untuk meningkatkan pengelolaan lansekap Monumen Puputan Klungkung.

\section{Metode Penelitian}

\subsection{Tempat dan Waktu Penelitian}

Penelitian dilakukan di Monumen Puputan Klungkung yang terletak di tengah kota Semarapura, selama tiga bulan dimulai dari bulan November 2016 sampai Februari 2017.

\subsection{Alat}

Alat yang digunakan meliputi alat tulis, kamera digital, perekam suara, meteran, lembar wawancara, lembar kuesioner serta perangkat komputer yang digunakan untuk mengolah data berupa AutoCAD 2013, Adobe Photoshop CS4 dan Microsoft Office 2010.

\subsection{Metode Penelitian}

Metode penelitian yang digunakan yaitu metode survei dengan teknik observasi, wawancara, kuesioner untuk data primer dan studi pustaka untuk data sekunder. Observasi merupakan pengamatan langsung kondisi tapak untuk mengetahui kondisi biofisik dan sosial budaya. Wawancara dilakukan dengan mengadakan tanya jawab langsung kepada Kepala Bidang Obyek Sarana dan Prasarana (konsep pengelolaan, 
peraturan tugas pengelola, alokasi dana pengelolaan monumen), pegawai kebersihan (hari libur dan frekuensi kegiatan pemeliharaan lansekap monumen) dan pengunjung Kertha Gosa (keberadaan monumen, tanggapan dan pandangan mengenai pengelolaan lansekap monumen). Kuesioner menggunakan teknik accidental sampling dengan memberikan angket atau daftar pertanyaan kepada responden, yang berisi pertanyaan mengenai persepsi dan preferensi pengunjung, pengembangan kawasan monumen, keinginan pengunjung mengenai bentuk lansekap dan aktivitas yang diinginkan, aktivitas sehari-hari dan rekreasi. Jenis kuesioner yang digunakan adalah kuesioner tertutup, yang ditujukan kepada 30\% dari populasi kunjungan berdasarkan observasi untuk menghasilkan analisis yang baik. Studi pustaka yaitu mencari data-data yang berhubungan dengan penelitian yang bersumber dari buku, jurnal, makalah, peraturan-peraturan dan media internet.

\subsection{Tahapan Penelitian}

Tahapan penelitian sesuai dengan kerangka pikir yaitu persiapan, inventarisasi, analisis dan sintesis berupa penyusunan rekomendasi pengelolaan lansekap monumen.

\subsubsection{Persiapan}

Persiapan berupa perijinan di lokasi dan pencarian umum tentang kondisi eksisting di lokasi penelitian, serta mempersiapkan alat yang diperlukan.

\subsubsection{Inventarisasi}

Inventarisasi merupakan tahap pengambilan data untuk mengetahui keadaan awal lansekap monumen berupa biofisik (luas, letak dan batas wilayah, iklim, elemen lunak dan keras, serta denah eksisting tapak), sosial budaya (pengelola, pengguna (karakteristik, persepsi dan preferensi pengunjung, volume kunjungan)), kebijakan (berkaitan dengan tugas pengelola lansekap monumen), dan ekonomi (alokasi dana terkait pengelolaan).

\subsubsection{Pengolahan Data dan Analisis}

Data dari ke empat aspek tersebut, kemudian dianalisis untuk mengetahui potensi dan kendala yang terdapat di monumen. Analisis yang digunakan berupa analisis deskriptif yang diartikan sebagai prosedur pemecahan masalah yang diselidiki dengan menggambarkan atau melukiskan keadaan objek penelitian pada saat sekarang berdasarkan fakta yang tampak atau sebagaimana adanya (Pradikta, 2013). Metode pengolahan data yang digunakan untuk mengolah data hasil studi pustaka berupa iklim adalah analisis indeks kenyamanan yang dilakukan dengan menghitung THI (Temperature Humidity Index). Niewolt (1998) menyatakan rumus pengukuran indeks kenyamanan adalah sebagai berikut:

$$
\mathrm{THI}=0,8 \mathrm{~T}+(\mathrm{RHXT}) / 500
$$

$$
\begin{aligned}
& \text { Keterangan: } \\
& \begin{array}{l}
\mathrm{THI}=\text { temperature humidity index } \\
\mathrm{T}=\text { suhu atau temperatur udara }\left({ }^{\circ} \mathrm{C}\right)
\end{array}
\end{aligned}
$$

Metode pengolahan data yang digunakan dalam mengolah data hasil observasi berupa pengamatan kapasitas kerja pemeliharaan taman adalah dengan perhitungan kapasitas kerja menurut Arifin dan Arifin (2005), dengan rumus sebagai berikut: 
Kapasitas Kerja $(K K)=\frac{\text { Luas Lahan }}{\text { Waktu X Jumlah Pekerja }}$

Metode pengolahan data yang digunakan dalam mengolah data hasil kuesioner dalam penelitan adalah tabulasi data dalam bentuk prosentase (\%). Menurut Sudjana (2001), rumus perhitungan persentase ini menggunakan:

$\mathrm{P}=\mathrm{F} / \mathrm{N} \times 100 \%$

Keterangan: $\mathrm{P}=$ Persentase $\mathrm{F}=$ Frekuensi $\mathrm{N}=\sum$ total responden

\subsubsection{Sintesis}

Melalui hasil analisis, maka disusun sintesis yang dilakukan berupa penyusunan rekomendasi pengelolaan lansekap Monumen Puputan Klungkung sebagai tapak bersejarah yang terdiri dari rekomendasi utama dan rekomendasi penunjang.

\subsection{Batasan Penelitian}

Lokasi penelitian dilakukan di kawasan Monumen Puputan Klungkung, Kabupaten Klungkung. Penelitian dilakukan sampai tahap sintesis dan hasil akhir yang diharapkan berupa rekomendasi utama dan rekomendasi penunjang pengelolaan lansekap untuk Monumen Puputan Klungkung secara deskriptif (deskripsi) dan spasial (zonasi ruang).

\section{Hasil dan Pembahasan}

\subsection{Inventarisasi Lokasi Penelitian}

\subsubsection{Aspek Biofisik}

Hasil pengamatan menunjukkan luas lansekap Monumen Puputan Klungkung yaitu $3.000 \mathrm{~m}^{2}$ dengan luas bangunan monumen $443,2 \mathrm{~m}^{2}$. Monumen terletak di tengah kota Semarapura dengan batas bagian Utara Pura Jagatnatha, bagian Timur pusat pertokoan dan pasar yang berada di seberang jalan raya, bagian Selatan Kertha Gosa yang berada di seberang jalan raya dan bagian Barat Gedung Kantor Bupati Klungkung. Suhu rata-rata Kabupaten Klungkung tahun 2014 adalah 26,40 , kelembaban udara 83\% dengan ratarata curah hujan $859 \mathrm{~mm}$ per tahun (BPS Provinsi Bali, 2015).

Hasil penelitian, terdapat 13 spesies tanaman dan 20 elemen keras dengan kondisi beragam. Perhatian lebih ditujukan pada kondisi tanaman maupun elemen keras yang kurang baik. Cyonodon stolon dan Carex morrowii mati akibat rembesan air mancur dan diinjak pengguna, Codiaeum variegatum dan Syzygium oleina merangas serta daun Chrysalidocarpus lutescens gosong akibat kekurangan pupuk, Bougainvillea sp. kurang dipangkas dan ditumbuhi gulma. Kolam air mancur ditumbuhi lumut dan air yang merembes keluar, tempat sampah dan lampu menyorot tanaman rusak dan perlu diperbaiki atau diganti, keran air yang kadang hidup kadang mati serta ada yang mengalami kebocoran, salah satu tiang gazebo rusak dimakan rayap dan terjadi perilaku vandalisme berupa coretan. Berdasarkan kondisi tersebut, tanaman dan elemen keras perlu mendapatkan pemeliharaan, perawatan, pemupukan bahkan penggantian.

I Nyoman Purnama (2016), gambar denah eksisting lansekap Monumen Puputan Klungkung belum ada karena masih tergantung pada dana, oleh karena itu penulis membuat gambar denah eksisting lansekap Monumen Puputan Klungkung (Gambar 1). 


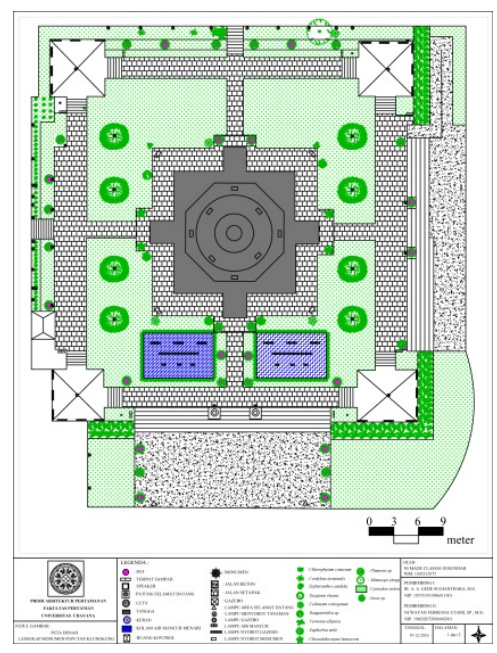

Gambar 1. Denah Eksisting Lansekap Monumen Puputan Klungkung

\subsubsection{Aspek Sosial Budaya}

Monumen Puputan Klungkung dibangun berawal dari raja Ida I Dewa Agung Jambe perang dengan Belanda, yang disimbolkan dengan adanya monumen (hasil wawancara dengan I Nyoman Purnama, 2016). Karakteristik, persepsi dan preferensi pengguna lansekap monumen diketahui melalui penyebaran kuesioner secara acak. Karakteristik pengunjung dibedakan berdasarkan usia, jenis kelamin, daerah asal dan pendidikan yang perlu dicari karena mempengaruhi jawaban kuesioner. Responden yang digunakan yaitu responden pada hari kerja $(\mathrm{HK})$ dan hari libur $(\mathrm{HL})$ untuk mendapatkan hasil analisis yang lebih baik. Hasil pengamatan di lapang menunjukkan volume kunjungan meningkat pada HL yaitu Sabtu dan Minggu sebanyak 79,4\% dari HK. Rata-rata kunjungan pada HK yaitu 24 orang, sedangkan pada HL 117 orang (Gambar 2).

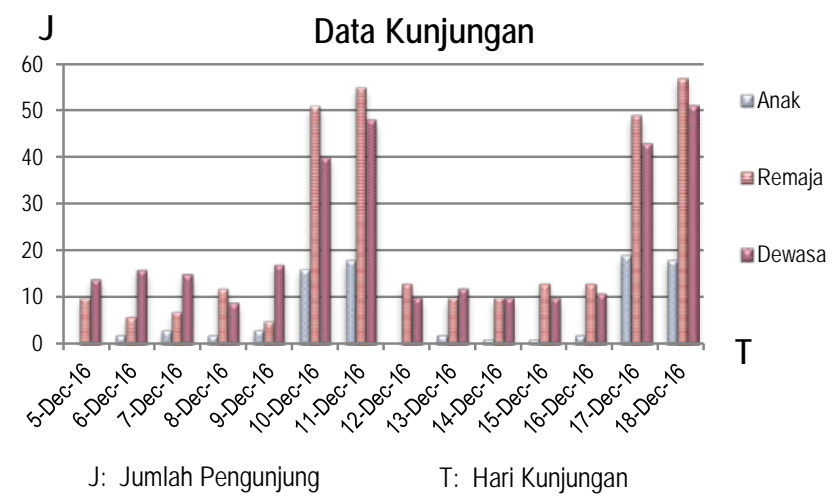

Gambar 2. Data Kunjungan Lansekap Monumen Puputan Klungkung

Responden pada HK 57\% mengetahui nama dari lokasi yang dikunjungi yaitu Monumen Puputan Klungkung, 29\% kurang tahu, 14\% tidak tahu, sedangkan responden HL 77\% tahu, 3\% kurang tahu, 20\% tidak tahu. Hasil penelitian pada HK maupun HL menunjukkan, perlu adanya signage sehingga pengunjung lebih mengetahui nama lokasi yang dikunjungi. Responden menyatakan bagian dalam monumen menarik 100\% pada HK, sedangkan pada HL 74\% sangat menarik, 9\% menarik, 14\% biasa saja, 3\% tidak menarik. Perlu adanya gagasan agar bagian dalam monumen dapat lebih menarik 
perhatian pengguna. Responden $57 \%$ tidak tertarik terhadap taman, $29 \%$ air mancur, $14 \%$ semua menarik pada HK, sedangkan responden $\mathrm{HL}$ 17\% taman, 69\% monumen dan 14\% air mancur. Taman dan air mancur perlu mendapat perhatian yang lebih, sehingga dapat menambah daya tarik dari lansekap monumen. Pengguna pada HK mengingingkan fasilitas toilet $43 \%$, loket informasi $29 \%$, WiFi $14 \%$ dan saklar $14 \%$, sedangkan pada $\mathrm{HL}$ $57 \%$ toilet, 23\% loket informasi, 11\% WiFi, 9\% saklar. Pengguna paling banyak menginginkan toilet mengingat pengguna rata-rata menghabiskan waktu satu sampai dua jam untuk mengunjungi lansekap monumen.

Permasalahan yang ditemui pada HK di lansekap monumen yaitu kurangnya fasilitas $57 \%$, kurangnya informasi pelayanan $43 \%$, sedangkan pada $\mathrm{HL}$, kurangnya fasilitas $54 \%$, kurangnya informasi pelayanan $23 \%$, fitur sejarah kurang terawat $6 \%$ dan $17 \%$ taman kurang terawat. Permasalahan utama di lansekap Monumen Puputan Klungkung yaitu kurangnya fasilitas, sehingga fasilitas perlu ditambahkan sesuai kebutuhan pengguna. Kurangnya informasi pelayanan, sehingga perlu sarana prasarana untuk mendapatkan informasi pelayanan. Fitur sejarah dan taman perlu ditingkatkan perawatannya.

\subsubsection{Aspek Kebijakan dan Ekonomi}

Peraturan berkaitan dengan tugas pengelola lansekap monumen termasuk di Tugas Pokok dan Fungsi (Tupoksi) terkandung dalam Peraturan Bupati Nomor 22 Tahun 2010 tentang Uraian Tugas dan Jabatan Struktural Perangkat Daerah Kabupaten Klungkung Pasal 70 (I Nyoman Purnama, 2016). Alokasi dana terkait kegiatan pengelolaan lansekap monumen menggunakan dana Anggran Pendapatan dan Belanja Daerah (APBD) DISBUDPAR Kabupaten Klungkung pada tahun 2015 yaitu 24 kegiatan dengan besar dana Rp. 7.248.450.000 (BPS Klungkung, 2016)

\subsection{Potensi dan Kendala Lansekap Monumen Puputan Klungkung}

Indeks kenyamanan dalam kondisi nyaman pada kisaran THI 20-26 (Diena, 2009). Hasil penelitian nilai indeks kenyamanan Kabupaten Klungkung yaitu 25,5 dan disimpulkan bahwa lansekap monumen berada dalam kondisi nyaman. Kondisi nyaman menunjukkan vegetasi di lansekap monumen sudah tercukupi, sehingga aktivitas berfoto sering dilakukan. Lansekap monumen berpotensi dikunjungi pengguna karena memiliki daya tarik sejarah perjuangan sekaligus tempat rekreasi. Kendala yang dihadapi pengelola yaitu belum memiliki badan pengelola khusus, sehingga pengelola kurang fokus dalam mengelola lansekap monumen (hasil wawancara dengan I Nyoman Purnama, 2016). Hasil wawancara dengan pengunjung Kertha Gosa, kurang adanya promosi terjadi pada lansekap monumen. Kurang optimalnya kinerja pemandu wisata, perilaku vandalisme (pengguna membuat pedestrian sendiri, anak-anak memanjat pinggiran tangga dan kolam air mancur) juga merupakan kendala di lansekap monumen.

Tupoksi cukup mengontrol pembagian tugas dalam pengelolaan monumen, namun belum adanya Standar Operasional Prosedur (SOP) pengelolaan monumen mengakibatkan pengelolaan belum berjalan optimal. Anggaran yang diusulkan pengelola masih mencukupi kegiatan operasional dalam skala prioritas seperti kegiatan 
pemeliharaan, perawatan dan pelestarian (I Nyoman Purnama, 2016). Apabila anggaran turun sesuai dengan yang diusulkan, kegiatan pengelolaan dapat berjalan optimal.

\subsection{Pengelolaan dan Evaluasi Pengelolaan Lansekap Monumen Puputan Klungkung}

DISBUDPAR berfungsi untuk menata, memelihara, mengelola, meningkatan sarana dan prasarana pada objek wisata di Klungkung (I Nyoman Purnama, 2016). Pengelolaan lansekap Monumen Puputan Klungkung, Kertha Gosa, Goa Lawah dan Kawasan Nusa Penida dikelola secara umum oleh Bidang Obyek Sarana dan Prasarana, terdiri dari tiga seksi yaitu Seksi Pengelolaan dan Pelestarian Objek, Seksi Pengendalian Sarana dan Prasarana Pariwisata dan Seksi Keramaian Rekreasi dan Hiburan.

Operasional pengelolaan lansekap Monumen Puputan Klungkung dimulai dari perencanaan dilakukan sesuai dengan rencana yang disusun pengelola, pelaksanaan program dilakukan sesuai dengan Tupoksi dan sudah terlaksana 80\%, pemeliharaan taman yang dilakukan masih di bawah kapasitas kerja pemeliharaan taman yang diajukan Arifin dan Arifin (2005) serta monitoring dan evaluasi yang dilakukan secara berkesinambungan. Tabel 1 menunjukkan kapasitas kerja pemeliharaan lansekap Monumen Puputan Klungkung, pada pekerjan menyapu lebih rendah 38\%, menyiram lebih rendah $60 \%$ dan penyiangan lebih rendah 38\%. Kelengkapan alat mendukung kelancaran kegiatan pemeliharaan taman yang dilakukan setiap hari, sehingga dapat berjalan secara efektif dan efisien (Arifin dan Arifin 2005). Perlu dilakukan format ulang, sehingga kapasitas pemeliharaan taman lansekap monumen menjadi ideal.

Tabel 1. Kapasitas Kerja Pemeliharaan Lansekap Monumen Puputan Klungkung

\begin{tabular}{|c|c|c|c|c|c|c|c|c|}
\hline \multirow[b]{2}{*}{ No } & \multirow{2}{*}{$\begin{array}{c}\text { Jenis } \\
\text { Pekerjaan }\end{array}$} & \multirow{2}{*}{$\begin{array}{l}\text { Jumlah } \\
\text { Pekerja }\end{array}$} & \multirow{2}{*}{$\begin{array}{l}\text { Luas } \\
\text { Area } \\
\left(\mathrm{m}^{2}\right)\end{array}$} & \multirow{2}{*}{$\begin{array}{l}\text { Waktu } \\
\text { (Jam) }\end{array}$} & \multicolumn{2}{|c|}{ Kapasitas Kerja } & \multicolumn{2}{|c|}{ Frekuensi Pemeliharaan } \\
\hline & & & & & $\begin{array}{c}* \\
\left(\mathrm{~m}^{2} / \mathrm{JaM}\right)\end{array}$ & ** (m²/Jam) & Kemarau & Hujan \\
\hline 1 & Menyapu & 3 & $\begin{array}{r}3.000 \mathrm{~m} \\
2\end{array}$ & 2 & 500 & 800 & Setiap hari & Setiap hari \\
\hline 2 & Menyiram & 3 & $\begin{array}{r}1.700 \mathrm{~m} \\
2\end{array}$ & 2 & 283 & 700 & $\begin{array}{l}2 \text { hari sekali } \\
\text { (tanaman } \\
\text { kecil) } \\
\text { Insidentil } \\
\text { (rumput) }\end{array}$ & $\begin{array}{l}\text { Insidentil } \\
\text { (tanaman } \\
\text { kecil dan } \\
\text { rumput) }\end{array}$ \\
\hline 3 & Memupuk & Insidentil & $\begin{array}{r}1.700 \mathrm{~m} \\
2\end{array}$ & & & & Insidentil & Insidentil \\
\hline 4 & $\begin{array}{l}\text { Pemangkasa } \\
\mathrm{n}\end{array}$ & 3 & $\begin{array}{r}1.700 \mathrm{~m} \\
2\end{array}$ & 2 & 283 & 250 & Setiap hari & Setiap hari \\
\hline 5 & Penyiangan & 3 & $150 m^{2}$ & 2 & 25 & 40 & Insidentil & Insidentil \\
\hline 6 & Penyulaman & Insidentil & & & & & Insidentil & Insidentil \\
\hline 7 & $\begin{array}{l}\text { Pemeliharaan } \\
\text { elemen keras }\end{array}$ & Insidentil & & & & & Insidentil & Insidentil \\
\hline
\end{tabular}

Keterangan: ( $\left.{ }^{\star}\right)$ Pengamatan lapangan di lansekap Monumen Puputan Klungkung

$\left.{ }^{(* *}\right)$ Kapasitas kerja pemeliharaan taman (Arifin dan Arifin, 2005)

\subsection{Rekomendasi Pengelolaan Lansekap Monumen Puputan Klungkung}

\subsubsection{Rekomendasi Utama}

Rekomendasi utama yaitu rekomendasi berdasarkan permasalahan utama di lapangan yaitu kurangnya fasilitas dan informasi pelayanan. Goldchild (1990), tindakan pelestarian sejarah dapat dilakukan dengan meningkatkan karakter sejarah pada tapak 
berdasarkan nilai sejarah. Penulis memberikan rekomendasi utama berupa solusi spasial Monumen Puputan Klungkung yang terdiri dari pembagian ruang, skema sirkulasi dan fungsi vegetasi yang mengacu pada nilai sejarah di tapak tersebut.
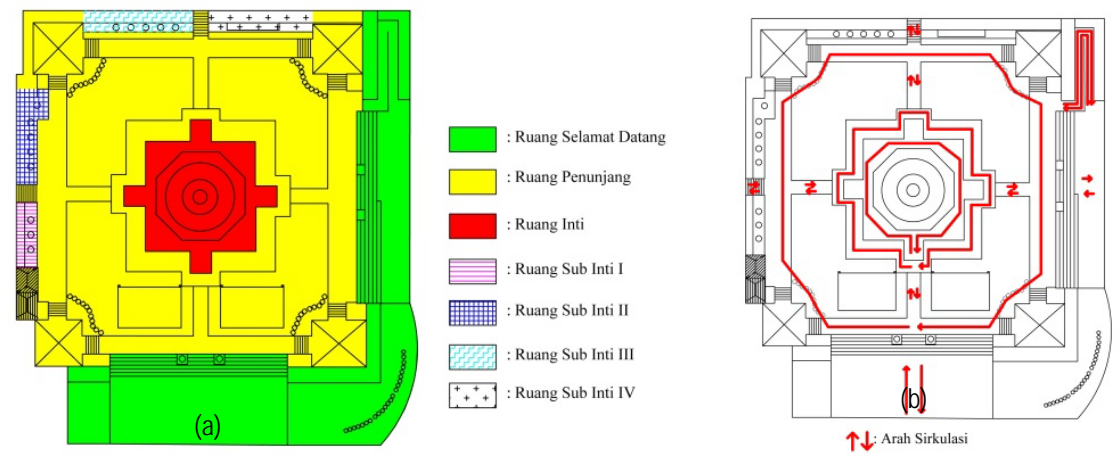

Gambar 3. Rekomendasi Pembagian Ruang (a) dan Sirkulasi (b)

Pembagian ruang awal lansekap Monumen Puputan Klungkung terdiri dari ruang inti (sarana edukasi), ruang penunjang (aktivitas di luar monumen) dan ruang selamat datang ( menerima pengunjung). Gambar 3 (a) merupakan rekomendasi pembagian ruang Monumen Puputan Klungkung. Ruang inti dilengkapi diorama, layar LED menceritakan kisah perang menggunakan animasi, serta patung raja Ida I Dewa Agung Jambe beserta pengikut yang dikelilingi kaca. Patung-patung dilengkapi pada ruang sub inti I (kedatangan pasukan Belanda), ruang sub inti II (perlawanan Kerajaan Klungkung) dan ruang sub inti III (runtuhnya Kerajaan Klungkung). Ruang sub inti IV dilengkapi dengan tugu nama-nama pahlawan Puputan Klungkung. Ruang penunjang dilengkapi gazebo, air mancur menari, pengeras suara, loket informasi serta menampilkan video animasi cahaya kisah Perang Puputan Klungkung di waktu malam hari melalui air mancur menari. Ruang selamat datang dilengkapi dengan signage Monumen Puputan Klungkung.

Skema sirkulasi awal Monumen Puputan Klungkung terdiri dari satu macam sirkulasi yaitu sirkulasi dua arah yang terjadi pada seluruh ruang. Rekomendasi skema sirkulasi (Gambar 3 b) Monumen Puputan Klungkung terdiri dari dua macam sirkulasi yaitu sirkulasi searah dan dua arah. Sirkulasi dipengaruhi oleh ruang berdasarkan jalan cerita Perang Puputan Klungkung. Rekomendasi vegetasi yang akan digunakan sesuai dengan jenis dan fungsi vegetasi (Tabel 3).

Tabel 3. Rekomendasi Vegetasi Sesuai dengan Fungsi dan Jenis Vegetasi

\begin{tabular}{|c|c|c|c|c|}
\hline \multirow{2}{*}{ No } & \multirow{2}{*}{ Ruang } & \multirow{2}{*}{ Fungsi Vegetasi } & \multicolumn{2}{|r|}{ Jenis Vegetasi } \\
\hline & & & Nama Indonesia & Nama Latin \\
\hline \multirow[t]{8}{*}{1} & Selamat datang & a. Pengarah & a. Krokot & a. Portulaca grandiflora \\
\hline & & b. Penutup & b Rumput jepang & b. Cynodon stolon \\
\hline & & $\operatorname{tanah}$ & c. Kembang kertas & c. Bougainvillea sp. \\
\hline & & c. Tabir & d. Janda merana, krokot & d. Vernonia elliptica, Portulaca \\
\hline & & d. Estetika & serat merah muda, & grandiflora, \\
\hline & & & dieffenbachia, lili paris & Dieffenbachia bowmannii, \\
\hline & & & & Chlorophytum \\
\hline & & & & Comosum \\
\hline
\end{tabular}




\begin{tabular}{|c|c|c|c|c|}
\hline \multirow{2}{*}{ No } & \multirow{2}{*}{ Ruang } & \multirow{2}{*}{ Fungsi Vegetasi } & \multicolumn{2}{|r|}{ Jenis Vegetasi } \\
\hline & & & Nama Indonesia & Nama Latin \\
\hline 2 & Penunjang & $\begin{array}{l}\text { b. Penutup } \\
\text { tanah } \\
\text { c. Estetika } \\
\text { d. Peneduh }\end{array}$ & $\begin{array}{l}\text { a. Lili paris, kacapiring, } \\
\text { kembang sepatu, soka, } \\
\text { kembang kertas } \\
\text { b. Rumput jepang } \\
\text { c. Lili paris, hanjuang, } \\
\text { pandan pudak } \\
\text { d. Kamboja, maja }\end{array}$ & $\begin{array}{l}\text { a. Chlorophytum comosum, Gardenia } \\
\text { jasminoides, Hibiscus rosa-sinensis, } \\
\text { Ixora sp., Bougainvillea sp. } \\
\text { b. Cyonodon stolon } \\
\text { c. Chlorophytum comosum, Cordyline } \\
\text { terminalis, Pandanus tectorius } \\
\text { d. Plumeria sp., Aegle marmelos }\end{array}$ \\
\hline 3 & $\begin{array}{l}\text { Sub Inti I } \\
\text { (representasi } \\
\text { kedatangan } \\
\text { pasukan Belanda) }\end{array}$ & $\begin{array}{l}\text { a. Pengarah } \\
\text { b. Penutup } \\
\text { tanah } \\
\text { c. Estetika }\end{array}$ & $\begin{array}{l}\text { a. Kalatea } \\
\text { b. Rumput jepang } \\
\text { c. Kembang sepatu } \\
\text { merah, } \\
\quad \text { lili peri merah muda, } \\
\text { krokot merah }\end{array}$ & $\begin{array}{l}\text { a. Calathea lutea } \\
\text { b. Cyonodon stolon } \\
\text { c. Hibiscus rosa-sinensis, Zephyranthes } \\
\text { grandiflora, Portulaca grandiflora }\end{array}$ \\
\hline 4 & $\begin{array}{l}\text { Sub Inti II } \\
\text { (representasi } \\
\text { perlawanan } \\
\text { Kerajaan } \\
\text { Klungkung) }\end{array}$ & $\begin{array}{l}\text { a. Pengarah } \\
\text { b. Penutup } \\
\text { tanah } \\
\text { c. Estetika }\end{array}$ & $\begin{array}{l}\text { a. Kalatea } \\
\text { b. Rumput jepang } \\
\text { c. Iris kuning, soka } \\
\text { kuning, } \\
\quad \text { krokot kuning }\end{array}$ & $\begin{array}{l}\text { a. Calathea lutea } \\
\text { b. Cyonodon stolon } \\
\text { c. Neomarica longifolia, Ixora sp., } \\
\text { Portulaca grandiflora }\end{array}$ \\
\hline 5 & $\begin{array}{l}\text { Sub Inti III } \\
\text { (representasi } \\
\text { runtuhnya } \\
\text { Kerajaan } \\
\text { Klungkung) }\end{array}$ & $\begin{array}{l}\text { a. Pengarah } \\
\text { b. Penutup } \\
\text { tanah } \\
\text { c. Estetika }\end{array}$ & $\begin{array}{l}\text { a. Kalatea } \\
\text { b. Rumput jepang } \\
\text { c. Anggrek tanah ungu, } \\
\text { kembang kertas ungu, } \\
\text { krokot ungu }\end{array}$ & $\begin{array}{l}\text { a. Calathea lutea } \\
\text { b. Cyonodon stolon } \\
\text { c. Spathoglotis plicata, Bougainvillea sp., } \\
\text { Portulaca grandiflora }\end{array}$ \\
\hline 6 & $\begin{array}{l}\text { Sub Inti IV } \\
\text { (tugu nama-nama } \\
\text { pahlawan Perang } \\
\text { Puputan } \\
\text { Klungkung) }\end{array}$ & $\begin{array}{l}\text { a. Pengarah } \\
\text { b. Penutup } \\
\text { tanah } \\
\text { c. Estetika }\end{array}$ & $\begin{array}{l}\text { a. Kalatea } \\
\text { b. Rumput jepang } \\
\text { c. Kacapiring, spider lily, } \\
\text { krokot putih }\end{array}$ & $\begin{array}{l}\text { a. Calathea lutea } \\
\text { b. Cyonodon stolon } \\
\text { c. Gardenia jasminoides, } \\
\quad \text { Hymenocallislittoralis, Portulaca } \\
\text { grandiflora }\end{array}$ \\
\hline
\end{tabular}

Berdasarkan rekomendasi pembagian ruang, rekomendasi skema sirkulasi dan rekomendasi vegetasi Monumen Puputan Klungkung, maka terbentuklah rekomendasi spasial pengelolaan lansekap Monumen Puputan Klungkung (Gambar 4). 


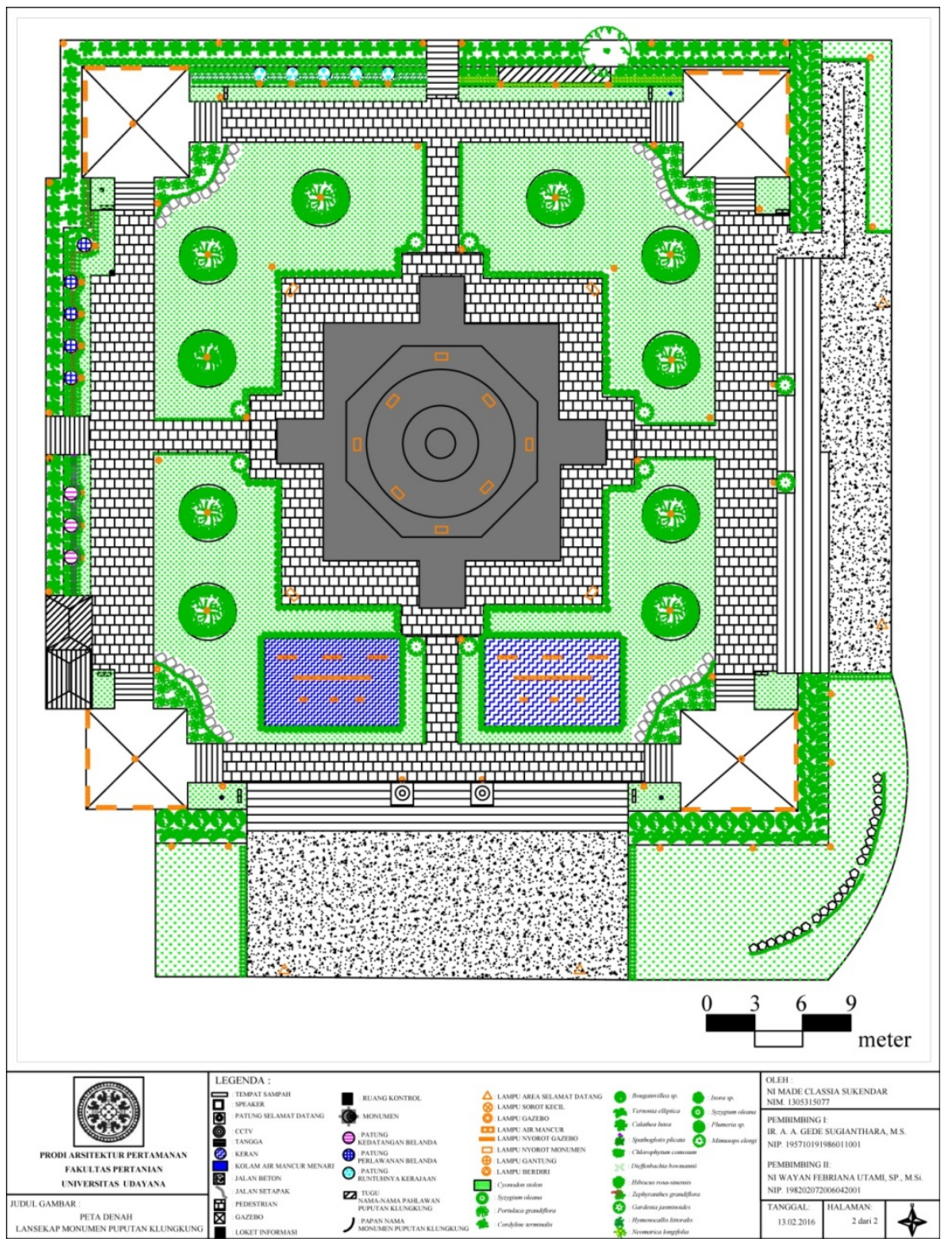

Gambar 4. Rekomendasi Spasial Pengelolaan Lansekap Monumen Puputan Klungkung

\subsubsection{Rekomendasi Penunjang}

Rekomendasi penunjang yaitu rekomendasi berdasarkan permasalahan yang didapat di lapang selain permasalahan utama. Rekomendasi penunjang dapat melengkapi rekomendasi utama, sehingga pengelolaan lansekap Monumen Puputan Klungkung dapat berjalan dengan optimal. Rekomendasi penunjang dari aspek biofisik berupa peningkatan fasilitas di area yang selama ini pemanfaatannya belum optimal serta peningkatan kegiatan pemeliharaan dan perawatan lansekap di Monumen Puputan Klungkung. Rekomendasi penunjang dari aspek sosial budaya berupa peningkatan efektivitas kerja pihak terkait dalam pengelolaan lansekap Monumen Puputan Klungkung, peningkatan pelayanan pengunjung melalui promosi untuk meningkatkan jumlah pengunjung oleh pengelola, serta penyusunan paket wisata bersamaan dengan objek wisata lain di Klungkung oleh pihak terkait. Rekomendasi penunjang dari aspek kebijakan berupa membentuk suatu badan pengelola khusus untuk struktur pemerintah serta penyusunan 
SOP untuk UPT Monumen Puputan Klungkung. Rekomendasi penunjang dari aspek ekonomi berupa penggunaan kartu elektronik sebagai tiket masuk ke paket City Tour.

\section{Simpulan dan Saran}

\subsection{Simpulan}

Operasional pengelolaan lansekap Monumen Puputan Klungkung dimulai dari perencanaan, pelaksanaan program, pemeliharaan, monitoring dan evaluasi. Perencanaan dilakukan sesuai dengan rencana yang disusun oleh pengelola (Dinas Kebudayaan dan Pariwisata Kabupaten Klungkung), pelaksanaan program dilakukan sesuai dengan Tupoksi dan sudah terlaksana $80 \%$, pemeliharaan taman yang dilakukan masih di bawah kapasitas kerja pemeliharaan taman, monitoring dan evaluasi dilakukan secara berkesinambungan. Solusi yang digunakan untuk meningkatkan pengelolaan lansekap Monumen Puputan Klungkung, sehingga kunjungan meningkat yaitu berupa rekomendasi utama dan rekomendasi penunjang. Rekomendasi utama berupa solusi spasial pengelolaan Monumen Puputan Klungkung yang terdiri dari rekomendasi pembagian ruang, skema sirkulasi dan vegetasi. Rekomendasi penunjang dilihat dari aspek biofisik, sosial budaya, kebijakan dan ekonomi.

\subsection{Saran}

Rekomendasi pengelolaan lansekap Monumen Puputan Klungkung diharapkan dapat menjadi bahan masukan bagi pengelola, sehingga dapat meningkatkan pengelolaan lansekap Monumen Puputan Klungkung.

\section{Daftar Pustaka}

Arifin, H. S. dan N. H. S. Arifin. 2005. Pemeliharaan Taman (Edisi Revisi). Penebar Swadaya. Jakarta. $169 \mathrm{hlm}$.

BPS Klungkung. 2016. Klungkung dalam Angka 2016. Badan Pusat Statistik 2016. 372 hlm.

BPS Provinsi Bali. 2015. Bali dalam Angka 2015. Badan Pusat Statistik 2015. $544 \mathrm{hlm}$.

Diena, A.L. 2009. Pengaruh Perubahan Penggunaan dan Penutupan Lahan terhadap Kenyamanan di Suburban Bogor Barat. Skripsi (tidak dipublikasikan). Program Studi Arsitektur Lansekap. Fakultas Pertanian Institut Pertanian Bogor.

Dinas Pariwisata Daerah Provinsi Bali. 2016. Jumlah Kunjungan Wisatawan pada ObjekObjek Wisata di Bali Tahun 2014 dan 2015. Tersedia secara online di: www.disparda.baliprov. go.id (diakses 25 Mei 2016).

Nieuwolt, S. 1998. Tropical Climatology, An Introduction to the Climates of the Low Latitude. New York. John Wiley and Sons. 352p.

Pradikta, Angga. 2013. Strategi Pengembangan Objek Wisata Waduk Gunungrowo Indah dalam Upaya meningkatkan Pendapatan Asli Daerah (PAD) Kabupaten Pati. Skripsi (tidak dipublikasikan). Universitas Negri Semarang.

Sudjana, Nana. 2001. Penelitian dan Penilaian Pendidikan. Sinar Baru. Bandung. 302 hlm. 